\title{
Intracystic Papillary Carcinoma in a Male Breast: Thirty Years after Orchiectomy
}

\author{
Vuka Katić ${ }^{1}$, Danijela Radojković ${ }^{2}$, Zoran Radovanović3 ${ }^{3}$ Ivan Nagorni ${ }^{4}$, Andrija Jović4, \\ Maja Nedić ${ }^{5}$ \\ ${ }^{1}$ Center for Pathology and Pathological Anatomy, Clinical Center Niš, Niš, Serbia \\ ${ }^{2}$ Clinic of Endocrinology, Clinical Center Niš, Niš, Serbia \\ ${ }^{3}$ Center of Radiology, Clinical Center Niš, Niš, Serbia \\ ${ }^{4}$ University of Niš, Faculty of Medicine, Niš, Serbia \\ ${ }^{5}$ Medical Center, Ražanj, Serbia
}

\section{SUMMARY}

Papillary carcinoma of the breast is an extremely rare form of breast carcinoma in males. We report a case of an 83-year-old man who presented with a retroareolar palpable mass, associated with bloody nipple discharge. Cytological characteristics were rare clusters and papillary formations with enlarged hyperchromatic nuclei, surrounded by erythrocytes. Having in mind that a reliable cytological diagnosis of papillary carcinoma cannot be made and that all papillary lesions observed in cytological material should be excised for histological examination, breast conserving surgery (BCS) was performed.

Histologically, cystic ducts were lined with atypical papillary formations bridging the duct lumen, but with the absence of both myoepithelial cells and stromal invasion. Prolactin and testosterone serum levels were decreased. Immunohistochemical examination on actin, estrogen and progesteron receptors was negative.

The authors have pointed out that the patient had left orchiectomy, induced by tuberculous orchiepididymitis with scrotal fistula, performed thirty years before. Twelve months after breast conserving surgery, the patient is still alive.

Key words: male breast papillary carcinoma, cytology, pathohistology, immunohistochemistry , tuberculous orchiepididymitis 


\section{INTRODUCTION}

Papillary carcinoma of the breast is an extremely rare form of breast carcinoma in males, with a handful of case reports in the literature entity (1-4). In contrast to the breast carcinoma in women (4), it tends to affect older age group having an excellent prognosis due to low malignant potential $(1,5,6)$.

The goal of the current study was to expand the knowledge regarding the cytological, histological and immunohistochemical characteristics, but also to suggest the possible pathogenesis of the male intracystic papillary breast carcinoma.

\section{CASE REPORT}

A 83-year-old male presented with bloody nipple discharge in the left breast occurring in the previous three months. Clinically, there was a palpable mobile retroareolar plaque like induration. The nipple and the overlying skin were normal. The right breast and the nodes in the axillary and supraclavicular fossa were not palpable. On ultrasonography, the mass was heterogenous with solid and cystic components, measuring 15 x $12 \mathrm{~mm}$. His past medical history included a diagnosis of pulmonary tuberculosis at the age of 18. Due to tuberculosis infection of testis and formed scrotal fistula, orhiectomy was performed 30 years before. His familial history was not significant. During the last 30 years of his life, he was in good health.

Cytological smears of the bloody nipple discharge were stained by HE (Haematoxylin and Eosin), PAP (Papanicolaou) and MGG (May Grünvald Gimsa) methods and analyzed three times, to the time of the breast conserving surgery (BCS). Paraffin sections were stained with HE, histochemical Van Gieson and immunohistochemical ABC methods, using the antibodies to actin, estrogen and progesterone receptors (Er and Pr). Cytologically, the atypical cells formed rare large cohesive clusters surrounded by erythrocytes and papillary formations with increased cellularity, irregular nuclear contour and hyperchromasia (Figure 1), suggesting the diagnosis of "an atypical papillary adenoma" .

Histological examination of specimens showed cystic dilatation of the ducts lined with papillary lesions, having the characteristics of non-invasive papillary carcinoma: round to polyhedral cells with mild nuclear atypia and hyperchromasia, but with rare mitoses. They were without the vascular connective tissue core, arranged in solid and micropapillary formations and forming cribriform pattern (Figure 2). Excision margins were free of tumor.

Immunohistochemical examination with antibodies to actin, estrogen and progesterone was negative. Serum prolactin $(5.2 \mathrm{ng} / \mathrm{ml})$ and testosterone $(1.22 \mathrm{ng} / \mathrm{ml})$ were at the normal level (Eliza).

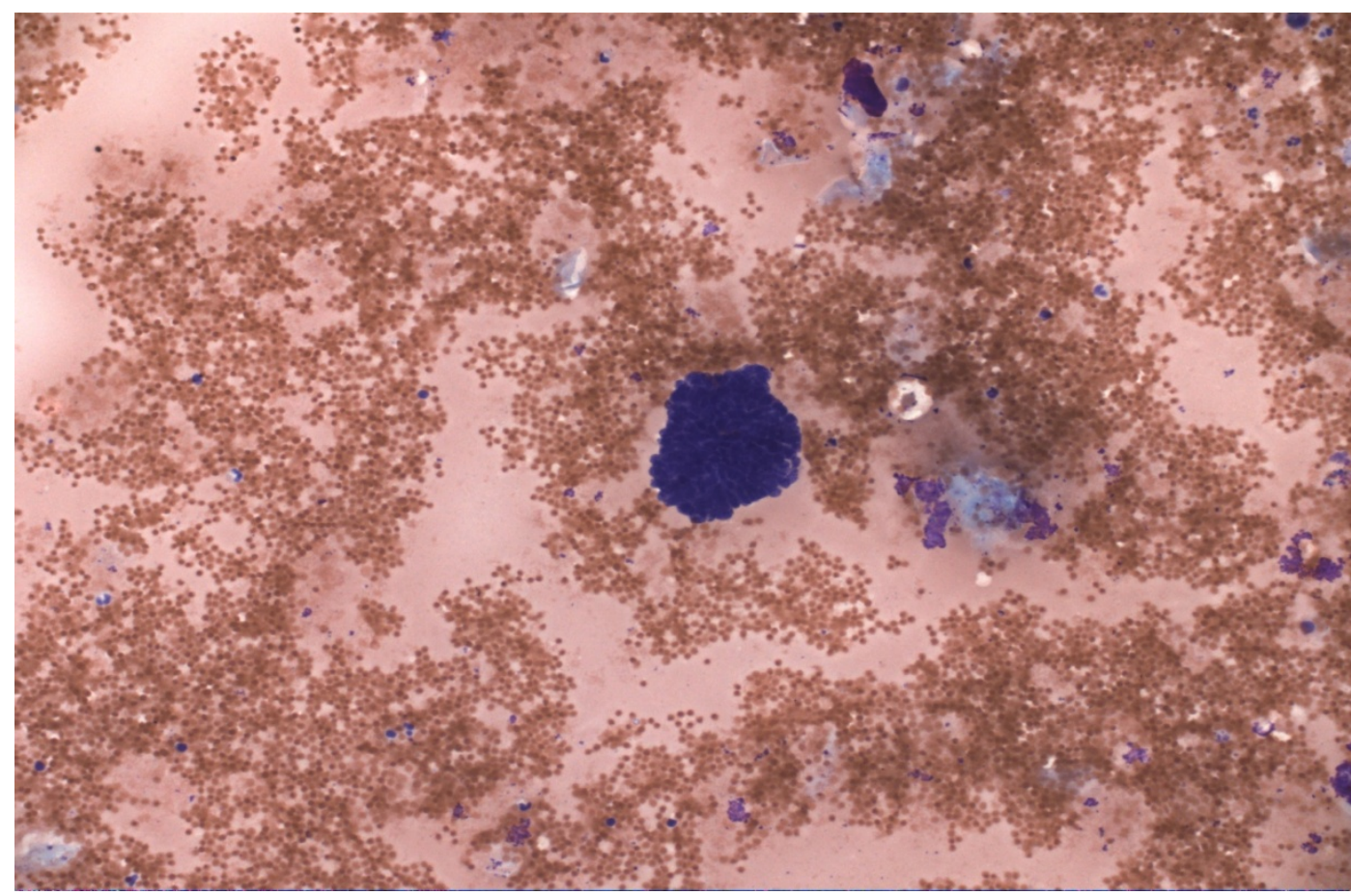

Figure 1. Cytological features of the male breast tumor: cluster of dysplastic cells, surrounded by erythrocytes. MGG x 300 


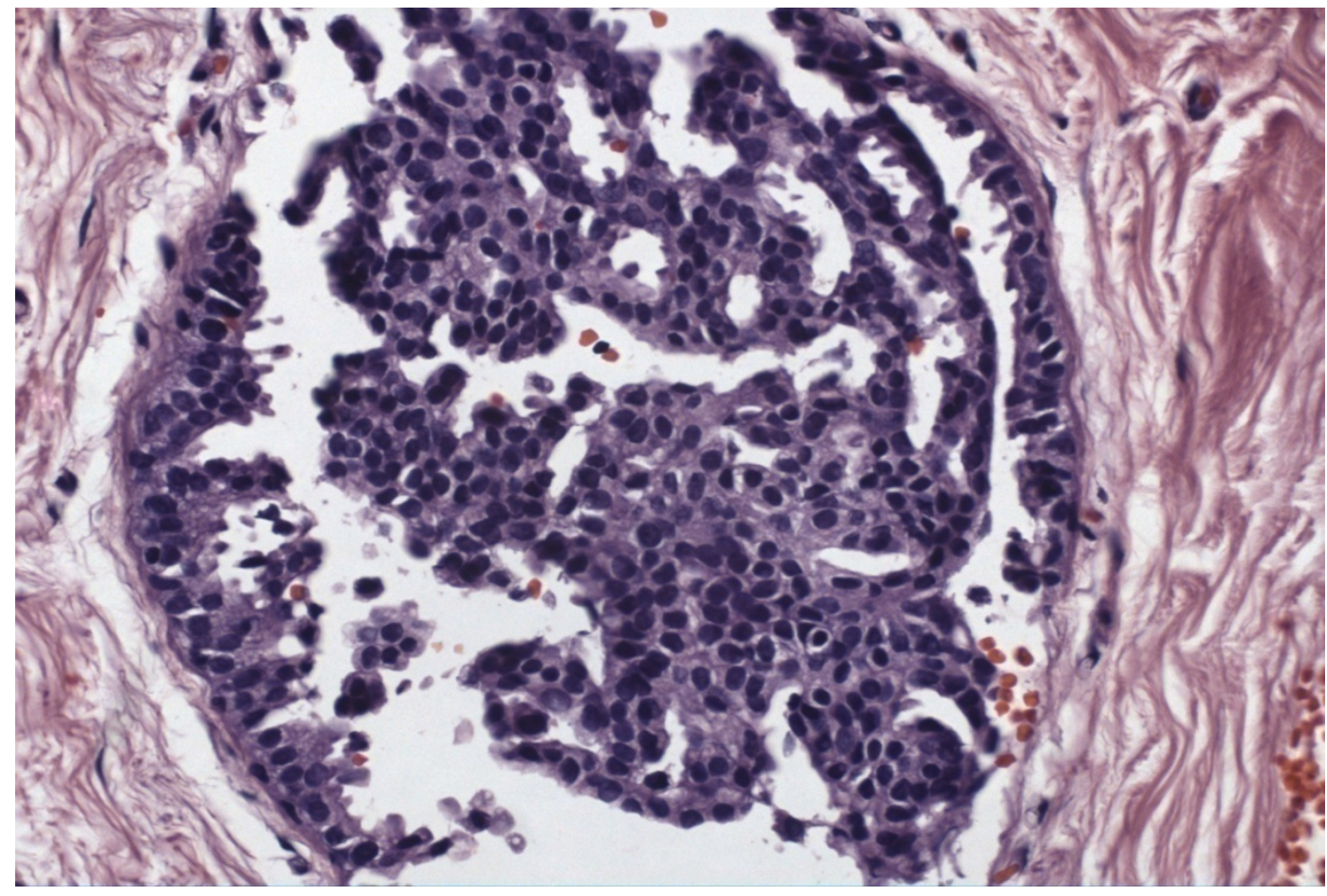

Figure 2. Cribriform pattern of intracystic papillary carcinoma. HE x 300

\section{DISCUSSION AND CONCLUSION}

Intracystic papillary carcinoma is a term used to describe a solitary, centrally located, malignant papillary proliferation involving a cystically dilated ducts (7-9). It is an extremely rare condition in men and accounts for $0.6 \%$ of all breast cancers (1, 3-5), with a favorable prognosis due to low malignant potential. Mean age of patients with male breast papillary carcinoma is 68.2 years $(2,4)$. Our patient was 83 years of age, being one of the oldest patients in this category $(4,8)$. Clinical presentation, mammographic appearance and ultrasonography are not specific $(1,6,7)$. Bloody nipple discharge, the clue clinical symptom for duct papillary carcinoma, directed us to repeat the cytological examination three times during one week and enabled us to discover an "atypical intracystic papilloma". Differential histological diagnosis between an atypical intracystic papilloma and intracystic papillary carcinoma was based on both histological and imunohistochemical examinations of the surgical biopsies (1,9-11).
From our results, we have excluded the possible role of prolactin, estrogen and progesterone in the pathogenesis of breast carcinoma $(11,12)$.

Our patient had unilateral orhiectomy thirty years before, caused by tuberculous infection. The decreased serum testosterone level in our patient not only confirms that it has an important role in the genesis of the male breast carcinoma but also explains the fact why the main victims of male breast cancer are elderly males.

The association of cancer and tuberculosis is well known (13). Mycobacterium tuberculosis-infected macrophages produce various cytokines and the most important is epiregulin, a potent epithelial growth factor for premalignant epithelial cells, indicating that chronic inflammation cased by tuberculosis may stimulate carcinogenesis $(14,15)$. Medical history of our patient was positive for tuberculosis which may contribute, with addition of other factors, to the development of breast cancer. The linkages between breast cancer and epiregulin is currently weak, but further investigation needs to be done.

Wide local surgical excision, without axillary dissection, is currently the treatment of choice. No other treatment was performed. He was doing well at the 12month follow-up. 


\section{References}

1. Rakha EA, Ahmed MA, Ellis IO. Papillary carcinoma of the breast: diagnostic agreement and management implications. Histopathology 2016; 69 :862-70.

https://doi.org/10.1111/his.13009

2. Gupta D, Torosian MH. Intracystic breast carcinoma in male: unusual case presentation and literature review. Oncol Rep 2002; 9: 405-7.

https://doi.org/10.3892/or.9.2.405

3. Andrés B, Aguilar J, Torroba A, et al. Intracystic papillary carcinoma in the male breast. Breast J 2003; 9: 249-50.

https://doi.org/10.1046/j.1524-4741.2003.09314.x

4. Kocic B, Filipovic S, Vrbic S, et al. Breast cancer in women under 40 years of age. J BUON 2011; 16: 63539.

5. Giordano SH, Cohen DS, Buzdar AU, et al. Breast carcinoma in men: a population-based study. Cancer 2004; 101: 51-7.

https://doi.org/10.1002/cncr.20312

6. Ying MW, Agrawal A, Cheung KL. The other half of breast cancer: A review of male breast cancer. J Mens Health Gend 2005; 2: 406-13.

https://doi.org/10.1016/j.jmhg.2005.10.012

7. Romics L, O'Brien MN, Relihan N, et al. Intracystic papillary carcinoma in a male as a rare presentation of breast cancer: a case report and literature review. J Med Case Rep 2009; 13: 3.

https://doi.org/10.1186/1752-1947-3-13
8. Estabrook A, Asch T, Gump F, et al. Mammographic features of intracystic lesions. Surg Gynecol Obstet 1990; 170: 113-6.

9. Koss LG, Melamed MR, editors. Koss' diagnostic cytology and its histopathologic bases. Lippincott Williams \& Wilkins; 2006.

10. Pal SK, Lau SK, Kruper L, et al. Papillary carcinoma of the breast: an overview. Breast Cancer Res Treat 2010; 122 :637-45.

https://doi.org/10.1007/s10549-010-0961-5

11. Turkoz FP, Solak M, Petekkaya I, et al. The prognostic impact of obesity on molecular subtypes of breast cancer in premenopausal women. J. BUON 2013; 18: 335-41.

12. Sørensen HT, Friis S, Olsen JH, et al. Risk of breast cancer in men with liver cirrhosis. Am J Gastroenterol 1998; 93: 231-3. https://doi.org/10.1111/j.1572-0241.1998.00231.x

13. Falagas ME, Kouranos VD, Athanassa Z, et al. Tuberculosis and malignancy. QJM. 2010;103:461-87 https://doi.org/10.1093/qimed/hcq068

14. Harikrishna, J, Sukaveni V, Kumar DP, et al. Cancer and tuberculosis. J Indian Acad Clin Med 2012; 13:142-4.

15. Riese DJ 2nd, Cullum RL. Epiregulin: roles in normal physiology and cancer. Semin Cell Dev Bio 2014; 28: 49-56.

https://doi.org/10.1016/j.semcdb.2014.03.005 


\title{
Intracistični papilarni karcinom u dojci muškarca: trideset godina nakon orhiektomije
}

\author{
Vuka Katić1, Danijela Radojković², Zoran Radovanović3 ${ }^{3}$ Ivan Nagorni, \\ Andrija Jović, ${ }^{4}$ Maja Nedić ${ }^{5}$
}

\author{
${ }^{1}$ Centar za patologiju i patološku anatomiju, Klinički centar Niš, Niš, Srbija \\ ${ }^{2}$ Klinika za endokrinologiju, Klinički centar Niš, Nišs, Srbija \\ ${ }^{3}$ Centar za radiologiju, Klinički centar Niš, Niš, Srbija \\ ${ }^{4}$ Univerzitet u Nišu, Medicinski fakultet, Niš, Srbija \\ ${ }^{5}$ Medicinski centar, Ražanj, Srbija
}

\section{SAŽETAK}

Papilarni karcinom je izuzetno redak karcinom dojke kod muškaraca. Prikazuje se bolesnik star 83 godine sa retroareolarnom palpabilnom masom udruženom sa krvavom sekrecijom iz dojke.

Na citološkom preparatu nađeno je prisustvo retkih klastera tumorskih ćelija i papilarnih formacija sa uvećanim hiperhromatskim jedrom okruženim eritrocitima. Imajući u vidu da pouzdana dijagnoza papilarnog karcinoma nije moguća na osnovu citološkog nalaza i da papilarne formacije nađene u citološkom materijalu zahtevaju biopsiju promene, izvršena je poštedna hirurška operacija dojke.

$\mathrm{Na}$ patohistološkom materijalu nađen je cistično prošireni duktus obložen atipičnim papilarnim formacijama, koje premošćuju njegov lumen, odsustvo mioepitelnih ćelija i stromalne invazije.

Serumske vrednosti prolaktina i testosterona bile su snižene. Imunohistohemijsko bojenje na aktin, estrogenske i progesteronske receptore bilo je negativno.

Autori naglašavaju da je bolesnik imao levu orhiektomiju izvršenu zbog tuberkuloznog epididimoorhitisa sa skrotalnom fistulom pre 30 godina. Dvanaest meseci nakon poštedne operacije dojke, bolesnik je zdrav.

Ključnereči: papilarni karcinom kod muškarca, citologija, patohistologija, imunohistohemija, tuberkulozni orhiepididimitis 